\title{
ANTITUMOR EFFECTS OF VANILLIN BASED CHALCONE ANALOGS IN VITRO
}

\author{
JOVAN LUKOVIĆ ${ }^{1}$, MARINA MITROVIĆ ${ }^{1}$, SUZANA POPOVIĆ \\ ZORAN MILOSAVLJEVIĆ́ ${ }^{3}$, MARIJANA STANOJEVIĆ-PIRKOVIĆ', \\ MARIJA ANĐELKOVIĆ ${ }^{1}$, IVANKA ZELEN ${ }^{*}$, MARIJA ŠORAK ${ }^{4}$, JOVANA MUŠKINJA ${ }^{5}$, \\ ZORAN RATKOVIĆ ${ }^{5}$ and IVANA NIKOLIĆ ${ }^{1}$
}
${ }^{1}$ Department of Biochemistry, Faculty of Medical Sciences, University of Kragujevac, Serbia ${ }^{2}$ Department of Microbiology and Immunology, Faculty of Medical Sciences, Center for Molecular Medicine and Stem Cell Research, University of Kragujevac, Serbia ${ }^{3}$ Department of Histology and Embryology, Faculty of Medical Sciences, University of Kragujevac, Serbia
${ }^{4}$ Department of Gynecology and Obstetrics, Faculty of Medical Sciences, University of Kragujevac, Serbia
${ }^{5}$ Department of Chemistry, Faculty of Science, University of Kragujevac, Radoja Domanovica 12, P.O. Box 60, Kragujevac, 34 000, Serbia

\begin{abstract}
Chalcones, as a large group of organic compounds, are widely implemented in various types of anticancer therapeutics. These plant metabolites are present in fruits, vegetables, spices, and have anti-tumor, antiinflammation, immunomodulation, antibacterial and anti-oxidative activities, as well as many other pharmacological and biological effects. The aim of the present study was to investigate cytotoxic effects, type of cell death and mechanism of action of the newly synthesized vanillin based chalcone analogs, $(\mathrm{CH} 1)$ and $(\mathrm{CH} 2)$ on human colon cancer HCT-116 and noncancerous (control) MRC-5 cell lines. In order to compare the effects of vanillin based chalcone analogs on investigated cell lines, as reference substances cisplatin (cisPt) and dehydrozingerone (DHZ) were used. Investigation of antitumor effect of chalcone analogs on HCT-116 cells was carried out by three methods MTT assay, flow cytometry and immunofluorescence analysis. The result of our investigation indicated that newly synthesized vanillin based chalcone analogs expressed powerful antitumor effect on cancer cells (HCT-116 cell line), while their effect on healthy cells (MRC-5 cell line) was not statistically significant. Vanillin based chalcone analogs caused overexpression and activation of mitochondrial Bax protein and caspase-3 in HCT-116 cells, indicating that their mechanism of antitumor action was mediated through activation of the inner apoptotic pathway. These results indicate possible usefulness of $\mathrm{CH} 1$ and $\mathrm{CH} 2$ in antitumor therapy whether through its direct cytotoxic effect or as adjuvant therapy. Our results indicate possible usefulness of $\mathrm{CH} 1$ and $\mathrm{CH} 2$ vanillin based chalcone analogs in antitumor therapy.
\end{abstract}

Keywords: chalcones, colorectal cancer, cytotoxicity, apoptosis, autophagy

Colorectal cancer (CRC) is the third most common malignancy worldwide. CRC represents $13 \%$ of all malignant tumors and it may be expected to overcome the mortality rate of patients with heart diseases in the near future $(1,2)$. Approximately, one half of the population in Western countries develops a colorectal tumor by the age of $70(3,4)$. However, this type of cancer is more frequent among younger population, due to obesity, bad nutritional habits, smoking and lack of physical activity (5). Colorectal cancer develops as a polyp or adenoma in the intestinal mucosa. Malignant transformation of benign changes depends on its size and histological presentation (1). In previous years, the survival rate of patients with metastatic colorectal cancer increased significantly due to the development and the application of new chemotherapy regimens (6).

There are several types of cell deaths, of which two are the main types: apoptosis and necrosis. Apoptosis, a programmed cell death, is character-

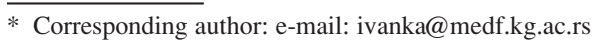


ized as nuclear condensation and fragmentation, cleavage of chromosomal DNA into internucleosomal fragments and formation of apoptotic bodies without plasma membrane breakdown (7). In contrast to apoptosis, necrosis is characterized morphologically with vacuolation of the cytoplasm, breakdown of the plasma membrane and induction of inflammation around the dying cell attributable to the release of cellular contents and pro-inflammatory molecules. Unlike these two types of cell death, autophagy is classified as a distinct form of nonapoptotic cell death. A crucial event in autophagy represents formation of autophagosome followed with the lysosome fusion and degradation of its content (7).

Chalcones are precursors of flavonoid biosynthesis that can be isolated from the plants or prepared synthetically by condensing aryl ketones with aromatic aldehydes in the presence of different condensing agents (8). According to their chemical structure, chalcones are $\alpha, \beta$ - unsaturated ketones with the one aromatic ring bonded to the carbonyl group and another aromatic ring bonded to the olefin group. All analogs and derivatives of chalcones, in their chemical structure, contain $\alpha, \beta$ - unsaturated carbonyl group. It has been shown that by incorporating $\alpha, \beta$ - unsaturated carbonyl group into a certain molecular structure augments the anticancer properties of the secondary natural products. For example, Heller et al. reported that the combination of $\alpha, \beta$ - unsaturated carbonyl sequence significantly increased the anticancer activity of triterpenoicacids compounds (9). Due to this, chalcones (as well as their derivatives and analogs) showed powerful biological activity, including the efficient

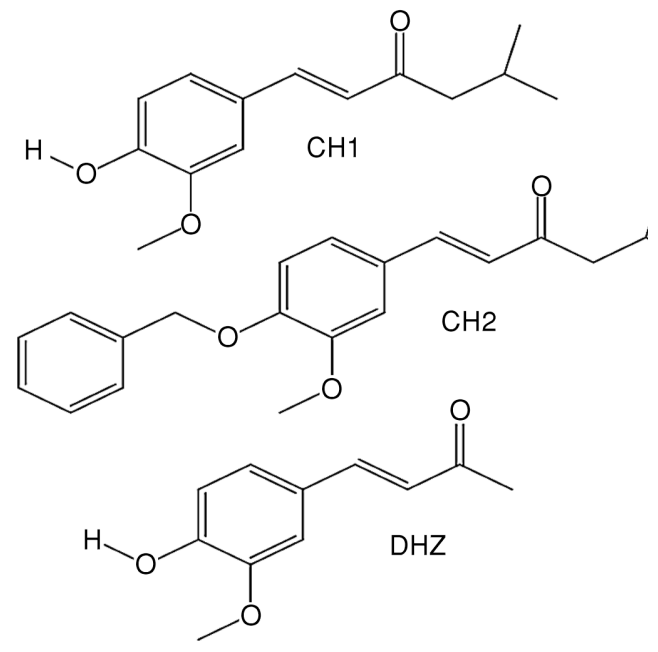

Figure 1. Structures of tested chalcone analogs. anti-tumor (10-12), anti-inflammatory (13, 14), and anti-oxidant (15-17) activities.

Here for the first time, we have investigated the antitumor effect of vanillin based chalcone analogs (E)-1-(4-hydroxy-3-methoxyphenyl)-5methylhex-1-en-3-one, (CH1) and (E)-1-(4-(benzyloxy)-3-methoxyphenyl)-5-methylhex-1-en-3-one (CH2) (Fig. 1) on human colorectal carcinoma cell line (HCT-116) and healthy MRC-5 cell line. CH1 and $\mathrm{CH} 2$ were previously synthesized by Muškinja et al. (18) and their antibacterial and antifungal activity was confirmed. As referent substances, we used cisplatin (cisPt) for which it was shown to exhibit an effective antitumor effect on different cancer cell lines $(19,20)$ and dehydrozingerone (DHZ) (21-23) which chemical structure is most similar with chemical structure of our investigated chalcones.

\section{EXPERIMENTAL}

\section{Cell culture, reagents and compounds}

Human colorectal carcinoma (HCT-116) and human fibroblast lung cell line (MRC-5) were obtained from the American Type Culture Collection $\left(\mathrm{ATCC}^{\circledR}\right.$ CCL-247TM and ATCC ${ }^{\circledR}$ CCL-171). The cells were maintained in complete DMEM (Dulbecco's Modified Eagle's medium, Sigma Aldrich D5671) supplemented with 10\% fetal bovine serum (FBS, Sigma-Aldrich, F7524), 100 $\mathrm{U} / \mathrm{mL}$ penicillin, $100 \mu \mathrm{g} / \mathrm{mL}$ streptomycin (both from Roche, 11074440001), and 1\% non-essential amino acid (Sigma-Aldrich, M7145) in a humidified atmosphere of $5 \% \mathrm{CO}_{2}$. Two synthesized vanillin based chalcone analogs and dehydrozingerone (DHZ) were a gift from the Faculty of Chemistry; University of Kragujevac; cisplatin (cisPt) was purchased from Calbiochem (CAS 15663-27-1). All tested substances were dissolved in DMSO (Sigma Chemical, ST. Lois, Mo) (total DMSO concentration of $0.5 \%$ ). Tested concentrations for $\mathrm{CH} 1$ and $\mathrm{CH} 2$ were $0.1,1,3,10,30,100$ and $300 \mu \mathrm{M}$, while for referent substances investigated concentrations were 3, 10, 30 and $100 \mu \mathrm{M}$. Chloroquine (CQ) was obtained from Sigma Aldrich (C6628) and dissolved in ultrapure water at a concentration of $20 \mu \mathrm{M}$.

\section{MTT assay}

In order to estimate the cytotoxicity of all investigated substances $(\mathrm{CH} 1, \mathrm{CH} 2, \mathrm{DHZ}$, and cisPt) on both experimental and control groups of cells, MTT assay was performed during 24 and $48 \mathrm{~h}$ incubation period. The cells were harvested from the culture flasks, counted, and $5 \times 10^{3}$ cells/well were 
seeded into 96-well plates and incubated for $24 \mathrm{~h}$. After incubation, HCT-166 and MRC-5 cells were treated with different concentrations of $\mathrm{CH} 1, \mathrm{CH} 2$ and referent substances and control cells were supplemented with complete growth medium. After 24 and $48 \mathrm{~h}$ treatment medium was removed and MTT solution $(5 \mathrm{mg} / \mathrm{mL})$ was added to the wells. After incubation, formazan crystals were solubilized using $100 \%$ dimethyl sulfoxide (DMSO). Optical density was measured at $595 \mathrm{~nm}$ using the microplate reader (Zenyth 3100, Anthos Labtec Instruments). The $\mathrm{IC}_{50}$ values for all tested substances were calculated using Microsoft Office Excel 2010. The percentage of cytotoxic cells was calculated using the formula: Cytotoxicity $(\%)=(1-($ exp. group $(\mathrm{ABS})) /(\mathrm{control}$ group $(\mathrm{ABS})) \times 100)$.

\section{Determination of apoptosis by flow cytometry Annexin V-FITC/7-AAD staining}

Type of cell death induced with investigated substances was determined with Annexin VFITC/7-AAD (cat. no 556547) (7-amino-actinomycin-D) staining using flow cytometry. HCT-116 cells were seeded in 24-well plate ( 1 x $10^{5}$ cells/well) and treated with $\mathrm{IC}_{50}$ values for all investigated substances during the $48 \mathrm{~h}$ period. In order to examine the effect of autophagy on the percentage of apoptotic cells, previous treatment with $20 \mu \mathrm{L}$ CQ was performed in experimental and control group of the cells. At the end of incubation period, cells were collected and washed 3 times with PBS, resuspended in $100 \mu \mathrm{L}$ of ice-cold $1 \mathrm{x}$ binding buffer, stained with $10 \mu \mathrm{L}$ of Annexin V-FITC and $20 \mu \mathrm{L}$ of 7 -AAD and incubated in the dark for $15 \mathrm{~min}$ at $+4^{\circ} \mathrm{C}$. Finally, $400 \mu \mathrm{L}$ binding buffer was added and the cells were analyzed by flow cytometer Cytomics FC500 (Beckman Coulter, USA). Data were analyzed using Flowing Software 2 and presented by dot plots.

\section{Flow cytometry analysis of apoptosis-related pro- teins}

In order to confirm induction of apoptosis with tested substances, we have determined changes in the expression levels of pro-apoptotic active Bax protein and percentage of cells containing cleaved, active caspase-3 as well. HCT-116 cells were treated with $\mathrm{IC}_{50}$ values of $\mathrm{CH} 1$ and $\mathrm{CH} 2$ or incubated in complete growth media (control) for $24 \mathrm{~h}$. Treated and untreated HCT-116 cells were washed with PBS, fixed, permeabilized (using Fixation and Permeabilization Kit, eBioscience) and stained separately for Bax and cleaved-caspase-3. The permeabilized cells were incubated with primary antibodies: anti-Bax (1 : 500) (N20, sc-493, Santa Cruz
Biotech. Inc) and anti-cleaved caspase-3 antibody (1 : 500) (\#9661, Cell signaling Technology, USA) for $30 \mathrm{~min}$ at room temperature. After incubation cells were washed and incubated with secondary 1 : 1000 Alexa 488-conjugated antibody (11001, Invitrogen, USA) for $15 \mathrm{~min}$. Following, cells were washed with PBS and analyzed by flow cytometry. Data were analyzed using Flowing Software 2. The expression Bax and active caspase- 3 were evaluated as mean fluorescence intensity (MFI).

\section{Autophagy detection by flow cytometry}

HCT-116 cells were seeded in 24-well plate $\left(1 \times 10^{5}\right.$ cells/well $)$ and treated for $24 \mathrm{~h}$ with $\mathrm{IC}_{50}$ values for all investigated substances. After incubated AO (acridine orange, $1 \mu \mathrm{g} / \mathrm{mL}$ ) was added to the wells. After 15 min of incubation autophagy was detected by flow cytometry. Data were analyzed using Flowing Software 2.

\section{Immunofluorescence analysis}

The HCT-116 cells were seeded on sterile glass coverslips and incubated for $24 \mathrm{~h}$ with $\mathrm{IC}_{50}$ values of $\mathrm{CH} 1$ and $\mathrm{CH} 2$. After incubation, cells were fixed in $4 \%$ paraformaldehyde for $30 \mathrm{~min}$ at room temperature. After permeabilization with $0.2 \%$ Tween 20 in PBS, cells were blocked in $0.1 \%$ Tween 20 in PBS (blocking buffer) for $30 \mathrm{~min}$ and then incubated with primary antibody (1:100 anticaspase-3, $1: 100$ active anti-Bax and $1: 100$ anti$\beta$-actin). After $1 \mathrm{~h}$, cells were washed in PBS and a secondary antibody (1: 200 Alexa 594, (gift from Dr. Ljubica Ivanišević, Ottawa, Canada) was added. After 30 min of incubation in the dark, immunofluorescence images were acquired on invert microscope Olympus BX51. Fluorescence intensity was measured using Image J software.

\section{Morphological analysis}

Observation of morphological changes of HCT-116 treated and control cells was performed using a phase-contrast microscope (Boeco, BM19, Germany) at 100x magnification. HCT-116 cells were seeded in 24 well plates and incubated for 24 h. After $48 \mathrm{~h}$ treatment with or without selected compounds (CH1, CH2, DHZ, and cisPt; concentrations of $3,10,30$ and $100 \mu \mathrm{M})$, morphological changes of both control and treated HCT-116 cells were visualized and compared under phase-contrast microscopy.

\section{Statistical analysis}

The data are presented as the mean \pm standard deviation for at least three repeated individual 
experiments for each group. Commercial SPSS version 20.0 was used for statistical analysis. The distributions of data were evaluated for normality using the Shapiro-Wilk test. Depending on data distribution statistical evaluation was performed by Student's t-test for paired observations.

\section{RESULTS}

Two of the new vanillin based chalcone analogs were synthesized in very good yields according to the procedures earlier described (18). Compound (CH1) was prepared by Claisen-Schmidt condensation of natural product vanillin and 4methylpentan-2-one. Alkylation of free phenolic group in $\mathrm{CH} 1, \mathrm{CH} 2$ of $\mathrm{O}$-alkyl derivative was obtained. The biological activity of chalcones was than evaluated against the colon cancer cell line HCT-116 and non-cancer human fibroblast cell line MRC-5. The first purpose of our study was to examine the cytotoxic effect of two chalcones analogs and compare them to the cytotoxic effect of referent substances (cisPt and DHZ) after 24 and $48 \mathrm{~h}$ treatment using 3-(4,5-dimethylthiazol-2-yl)-2,5-di phenyl tetrazolium bromide (MTT) assay (Figs. 2 and 3). Also, one of the first aims was to evaluate the cytotoxic effect of chalcone analogs on noncancer human fibroblast cell line MRC-5 (Fig. 3). The first results indicated that hydroxyl $(\mathrm{CH} 1)$ and benzyloxy group $(\mathrm{CH} 2)$ on the aromatic ring of these chalcones resulted in different cytotoxic effect after $24 \mathrm{~h}$ and $48 \mathrm{~h}$ of treatment (Figs. 2A and B). MTT results showed that $\mathrm{CH} 1$ analog exhibited stronger cytotoxic effect compared to $\mathrm{CH} 2$ analog. In the case of the lowest applied dose $(0.3 \mu \mathrm{M}), \mathrm{CH} 1$ analog resulted in $11.77 \%$, while $\mathrm{CH} 2$ had $0.32 \%$ of cytotoxic HCT116 cells during $24 \mathrm{~h}$ treatment. The highest applied dose $(300 \mu \mathrm{M})$ of chalcone analogs resulted in $60.27 \%(\mathrm{CH} 1)$ and $46.30 \%(\mathrm{CH} 2)$ of cytotoxic HCT-116 cells during $24 \mathrm{~h}$ treatment. The lowest dose of chalcone analogs used during the $48 \mathrm{~h}$ period resulted in $47.55 \%(\mathrm{CH} 1)$ and $13.27 \%(\mathrm{CH} 2)$; while the highest applied dose resulted in $82.29 \%(\mathrm{CH} 1)$ and $50.06 \%$ (CH3) of cytotoxic HCT-116 cells.

After we have determined the cytotoxic effect of chalcone analogs our next aim was to compare their cytotoxic effect to the cytotoxic effect of the reference substances (cisPt and DHZ) (Fig. 3) on HCT-116 and noncancerous MRC-5 cell line during 24 and $48 \mathrm{~h}$.

Our results clearly showed that all investigated substances caused a significant increase in the per-
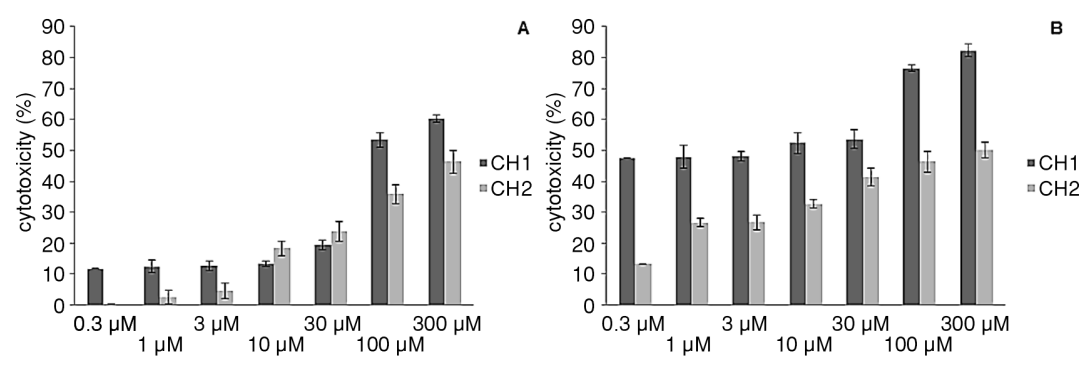

Figure 2. The cytotoxic effects of the various concentrations of $\mathrm{CH} 1$ and $\mathrm{CH} 2$ on HCT-116 cells after $24 \mathrm{~h}(\mathrm{~A})$ and $48 \mathrm{~h}$ (B) of treatments.
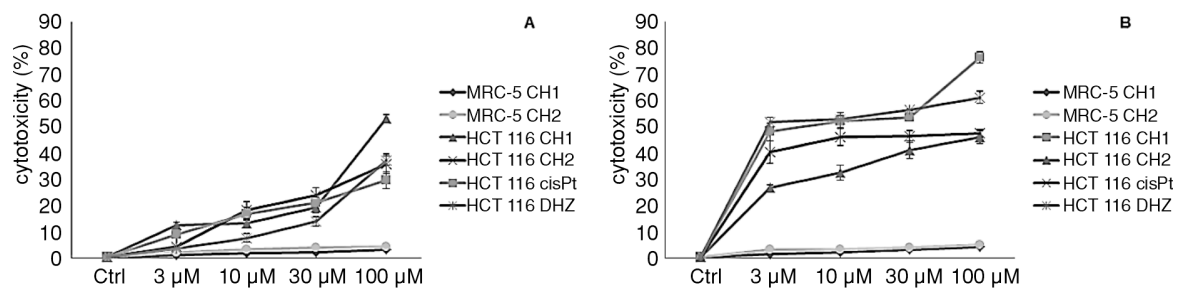

Figure 3. Comparison of the cytotoxic effects of $\mathrm{CH} 1, \mathrm{CH} 2$ and referent substances (cisPt and DHZ) on HCT-116 and MRC-5 cells after $24 \mathrm{~h}(\mathrm{~A})$ and $48 \mathrm{~h}(\mathrm{~B})$ of treatments. Selective cytotoxic effect of $\mathrm{CH} 1$ and $\mathrm{CH} 2$ against cancer cells. 
Table 1. Cytotoxic activity $\left(\mathrm{IC}_{50}\right.$ values $\left.(\mu \mathrm{M})\right)$ of chalcone analogs $(\mathrm{CH} 1, \mathrm{CH} 2)$, cisplatin $($ cisPt) and dehydrozingerone $(\mathrm{DHZ})$ against HCT-116 human cancer cell line and noncancerous MRC-5 cell line after 24 and $48 \mathrm{~h}$ treatment.

\begin{tabular}{|c|c|c|c|c|}
\hline $\mathrm{IC}_{50}$ & $\mathrm{CH} 1$ & $\mathrm{CH} 2$ & cisPt & DHZ \\
\hline HCT-116 24 h & $6.85 \pm 0.71$ & $7.9 \pm 1.37$ & $7.17 \pm 1.15$ & $5.71 \pm 0.66$ \\
\hline HCT-116 48 h & $2.65 \pm 0.87$ & $6.76 \pm 0.92$ & $4.82 \pm 1.45$ & $2.85 \pm 0.69$ \\
\hline MRC-5 24 h & $>200$ & $>200$ & $>150$ & $>300$ \\
\hline MRC-5 48 h & $>200$ & $>200$ & $>40$ & $>300$ \\
\hline
\end{tabular}

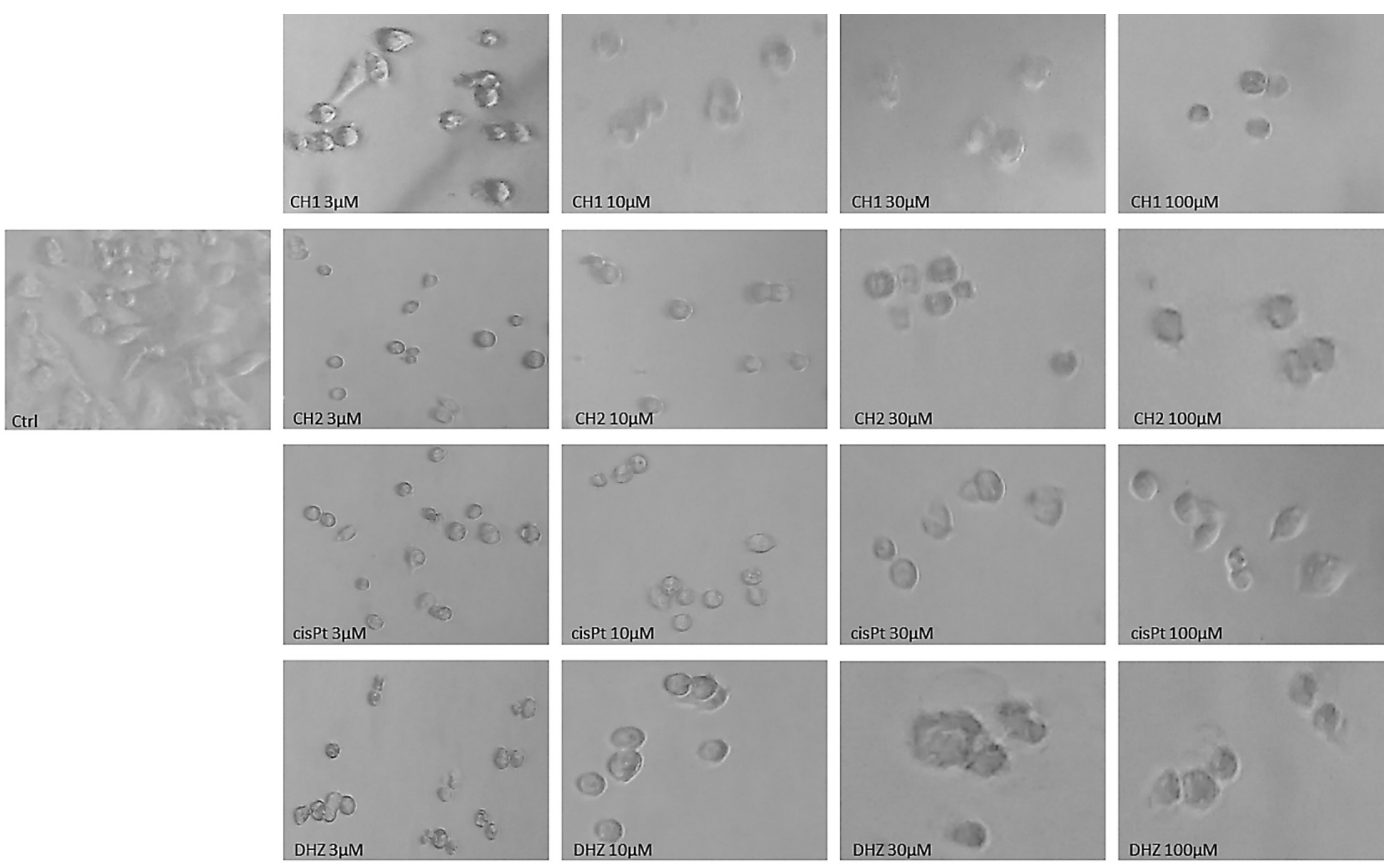

Figure 4. Changes of the HCT-116 cells morphology after $48 \mathrm{~h}$ treatment with all investigated substances (different concentrations of CH1, $\mathrm{CH} 2$, cisPt, and DHZ). Both of $\mathrm{CH} 1$ and $\mathrm{CH} 2$ induced morphological changes of the HCT-116 cells in a dose-dependent manner. Morphological changes were in direct correlation with MTT results. Morphology of the treated HCT-116 cells was significantly impaired compared to the untreated HCT-116 cells.

centage of cytotoxic HCT-116 cancer cells, while there was no statistically significant cytotoxic effect on healthy fibroblast cell line (MRC-5) during $24 \mathrm{~h}$ and $48 \mathrm{~h}$ period (Fig. 3). The calculated $\mathrm{IC}_{50}$ values for $\mathrm{CH} 1, \mathrm{CH} 2$, cisPt, and $\mathrm{DHZ}$ are presented in Table 1 . The calculated $\mathrm{IC}_{50}$ values clearly showed that all investigated substances significantly decreased HCT-116 cells viability in vitro in a dosedependent manner after 24 and $48 \mathrm{~h}$ of treatment. After $24 \mathrm{~h}$ treatment, $\mathrm{IC}_{50}$ values of all investigated agents were similar $\left(\mathrm{CH} 1\right.$ and $\mathrm{CH} 2$ with $\mathrm{IC}_{50}$ value of $6.85 \pm 0.71,7.9 \pm 1.37$, respectively; cisPt and $\mathrm{DHZ}$ with $\mathrm{IC}_{50}$ value of $7.17 \pm 1.15,5.71 \pm 0.66$ $\mu \mathrm{M}) .24 \mathrm{~h}$ treatment with all investigated substances had high $\mathrm{IC}_{50}$ values on noncancerous MRC-5 cell line $\left(\mathrm{IC}_{50}\right.$ for $\mathrm{CH} 1, \mathrm{CH} 2$ was $>200 \mu \mathrm{M}, \mathrm{DHZ}>300$ $\mu \mathrm{M}$ and cisPt $>150 \mu \mathrm{M}) .48 \mathrm{~h}$ treatment of HCT -116 cells lowered $\mathrm{IC}_{50}$ values for all investigated agents (CH1 and $\mathrm{CH} 22.65 \pm 0.87,6.76 \pm 0.92$, respectively; cisPt and DHZ $4.82 \pm 1.4$ and $2.85 \pm 0.69 \mu \mathrm{M}$ ). However $\mathrm{IC}_{50}$ values for MRC-5 cell lines remained high for 48 treatments (Table 1).

In order to assess alterations of cell morphology subsequent to chalcone analog treatments, HCT-116 cells were grown in 24 well plates. Untreated, control HCT-116 cells were homogeneously distributed and adherent on the cultured field with maintained original morphology form observed by phase-contrast microscopy (Fig. 4). In contrast, chalcone analog exposed HCT-116 cancer 
cells, revealed typical apoptotic features such as cell rounding, shrinkage and membrane blebbing with adherence loss. Our results showed that the level of HCT-116 morphological changes was dose-dependent (Fig. 4). Thus, the concentration of investigated agents of 30 and $100 \mu \mathrm{M}$ resulted in a complete loss of cell morphology, as previously shown by the results obtained by MTT assay.

According to the results obtained by MTT test and morphological analysis, the next experiment was performed in order to analyze the type of cell death and quantify apoptotic cells. Flow cytometry was used in order to measure Annexin V-FITC/7AAD stained cells which confirmed the induction of apoptosis in human HCT-116 cell line with calculated $\mathrm{IC}_{50}$ values for all investigated substances (Fig. 5).

The type of cell death induced with all investigated agents $(\mathrm{CH} 1, \mathrm{CH} 2$, cisPt, and $\mathrm{DHZ})$ during $48 \mathrm{~h}$ resulted in a high percentage of early and late

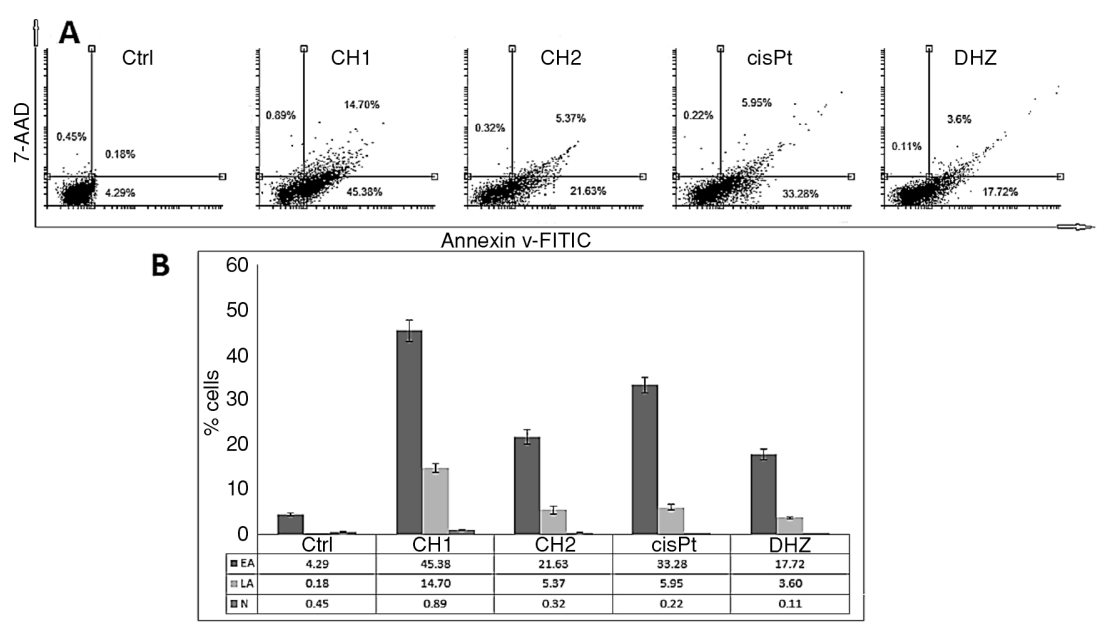

Figure 5. A) HCT-116 cancer cells were treated as indicated for $48 \mathrm{~h}$, fixed in 70\% ethanol, stained with 7-AAD (7-amino-actinomycinD) and analyzed by flow cytometry for apoptosis. Upper left square - necrosis (\%); bottom right square - early apoptosis (\%); upper right square - late apoptosis. B) Summary of the apoptosis data in bar chart. Data are expressed as the mean \pm standard error of the mean (SEM) from at least three independent experiments.

A

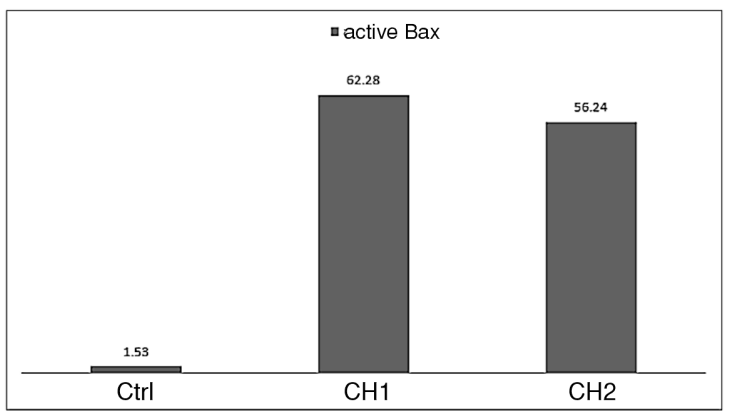

B

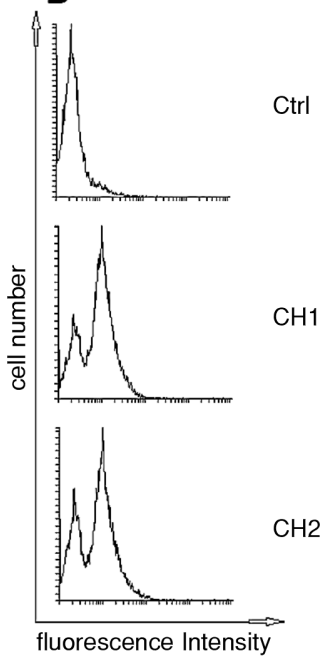

Figure 6. The expression levels of active, mitochondrial Bax in HCT-116 cells after $24 \mathrm{~h}$ of treatment. Flow cytometry analysis of apoptotic and nonapoptotic populations for active Bax in HCT-116 cells. Bar panel (A) indicates Bax activation as fold increase compared to control. Histograms (B panel) show untreated (control) cells were primarily negative for active Bax; whereas treated cells with CH1 and $\mathrm{CH} 2$ were positive for active Bax. 
A

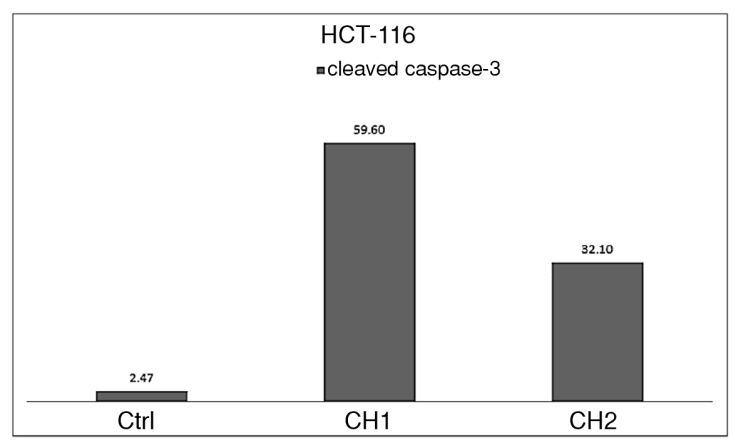

B

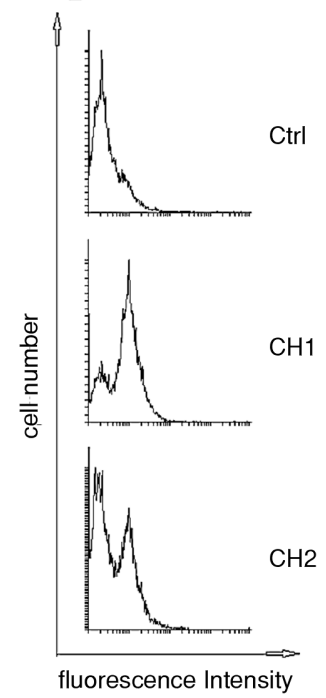

Figure 7. The expression levels of cleaved caspase-3 HCT-116 cells after $24 \mathrm{~h}$ treatment. Flow cytometry analysis of apoptotic and nonapoptotic populations for active caspase-3 in HCT-116 cells. Bar panel A indicates caspase-3 activation as fold increase compared to control cells. Histograms (B panel) show untreated (control) cells were primarily negative for the presence of active caspase-3; whereas treated cells with $\mathrm{CH} 1$ and $\mathrm{CH} 2$ were positive for active caspase-3.

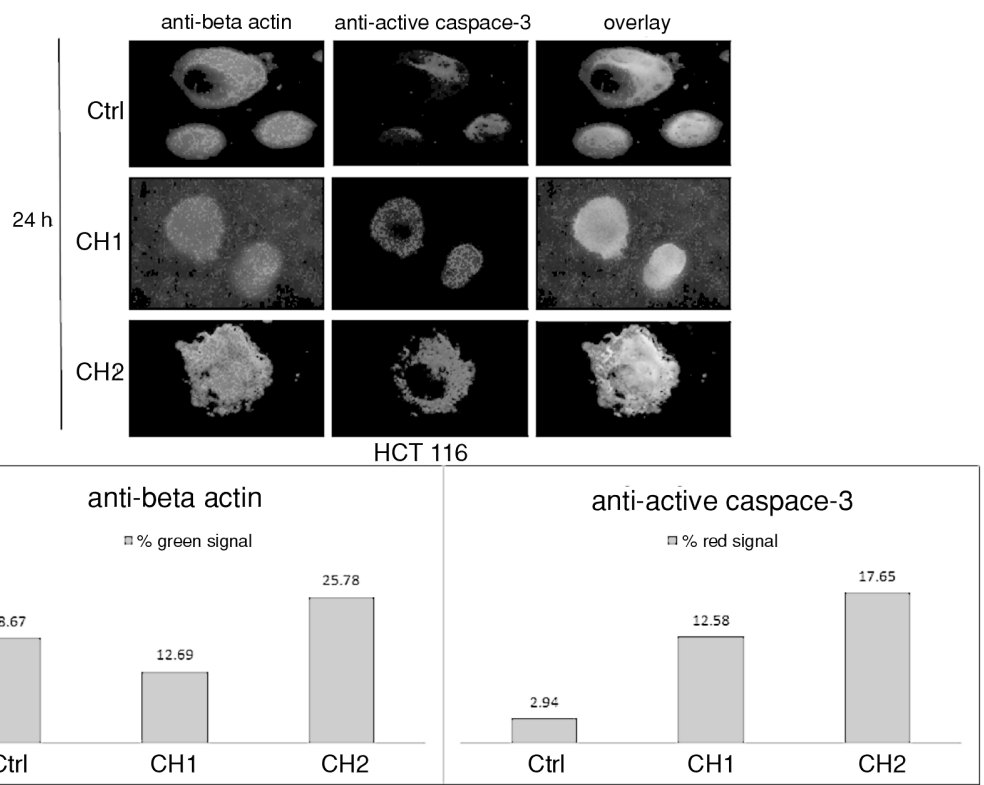

Figure 8. HCT-116 cells were co-immunostained for actin (green) and active caspase-3 (red). Immunofluorescence microscopy was used to confirm the expression levels of cleaved caspase- 3 in HCT-116 cells after $24 \mathrm{~h}$ chalcone treatment.

apoptotic cells, while the percentage of necrotic cells was negligible (Figs. 5A and B). As expected all investigated substances increased the number of apoptotic cells. $4.29 \%$ of control HCT-116 cells were in the early stage of apoptosis, whereas treated HCT-116 cells exhibited statistically significant increase of cells in the early stage of apoptosis (CH1-45.38\%; CH2-21.63\%; cisPt-33.28 and DHZ-
$17.72 \%)$. However, the percentage of the cells in the late stage of apoptosis (CH1-14.70\%; $\mathrm{CH} 2-5.37 \%$; cisPt-5.95\% and DHZ-3.60\%) and the percentage of necrotic cells (CH1-0.89\%; $\mathrm{CH} 2-0.32 \%$; cisPt$0.22 \%$ and DHZ- $0.11 \%$ ) didn't show a significant increase, respectively.

Our results presented in Figure 5 demonstrated that both chalcone analogs stimulate human HCT- 
116 cells to initiate apoptosis as the main cell death mechanism requiring caspase activity.

In order to capture adequate apoptotic signal and changes in the expression levels of crucial apoptotic proteins, our next experiments were directed towards $24 \mathrm{~h}$ treatments. Since both chalcone analogs showed significant cytotoxic and apoptotic effects (total apoptosis, both early stage of apoptosis and late stage of apoptosis) on HCT-116 cells, next we have investigated their apoptotic mechanism by analyzing the expression level of active Bax using flow analysis (Fig. 6). In healthy cells, Bax is predominantly cytosolic protein. However, the induction of apoptotic stimuli induce changes in Bax conformation and converts Bax into pore-forming protein in the the outer mitochondrial membrane. Formation of pores in outer mitochondrial membrane causes release of cytochrome $\mathrm{c}$, formation of apoptosome and cleavage of procaspase-3. Our results indicate that treatment of HCT-116 cells with investigated chalcones caused overexpression of active, mitochondrial Bax (CH1 - 62.28 and $\mathrm{CH} 2$ - 56.24\%) compared to control cells (1.53\%) (Figs. 6A and B). This result indicated that chalcone analogs induced translocation of cytosolic Bax, outer mitochondrial membrane pore formation and complete disruption of mitochondrial membrane integrity resulting in cell death.

In order to further investigate the mechanism of chalcone analog induced apoptosis in HCT-116 cells, we focused on the hypothesis that detection of cleaved caspase- 3 could be a good marker for chalcone induced apoptosis. HCT-116 treated and con- trol cells were labeled with the anti-cleaved caspase- 3 antibody and analyzed by flow cytometry.

Results indicated statistically significantly higher expression level of cleaved caspase- 3 in treated HCT-116 cells compared to the control cells (Fig. 7). The cells treated with $\mathrm{CH} 1$ analog showed 30 times fold increase of active caspase-3 (59.60\%) compared to the control cells $(2.47 \%)$ and nearly 15 fold increase compared to the $\mathrm{CH} 2$ treated cells (32.10\%) (Fig. 7).

Consistent with the presence of caspase-3 activity in HCT-116 cells, the activation of caspase-3 was also further detected and confirmed using immunofluorescence staining against the cleaved caspase- 3 following $24 \mathrm{~h}$ chalcone treatment (Fig. 8).

Under $24 \mathrm{~h}$ exposure to $\mathrm{IC}_{50}$ values of chalcone analogs, HCT-116 cells stained positive for active caspase-3 (CH1 - 12.58 and $\mathrm{CH} 2-17.65 \%)$, indicating the progression of apoptosis in the treated cell population compared to control cells (2.94\%).

After determining the apoptotic effect of investigated substances, we examined whether autophagy is involved in the cytotoxic effect of tested substances. Flow cytometry analysis of AO stained cells showed that both substances significantly increased percent of red/green cells indicating induction of autophagy (Figs. 9A and B). To find out the role of autophagy in apoptosis induced with tested substances, cells were co-treated with CQ. While inhibition of autophagy had no influence on $\mathrm{CH} 2$ - induced apoptosis, in CH1-treated cells resulted in a decrease of Annexin V-positive cells (Figs. 9C
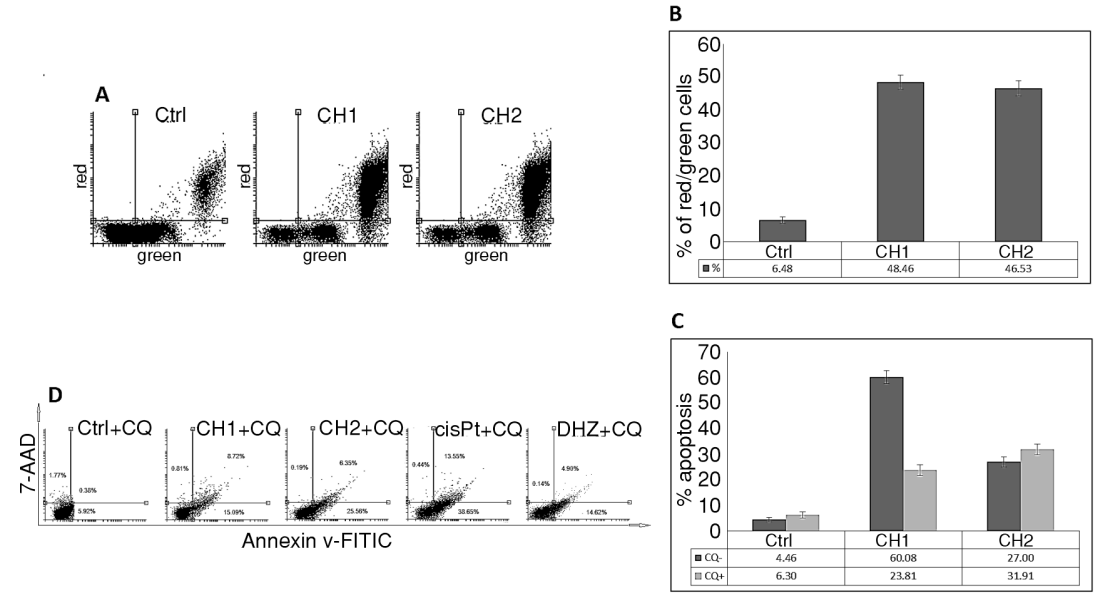

Figure 9. Autophagy detection. Results of AO staining of treated and untreated (control) cells are presented by representative dot plots (A) and graph (B). The results of Annexin V/7-AAD staining of control and treated cells co-incubated with autophagy inhibitor (CQ) are presented by representative dot plots (C) and graph (D). Graphs show mean \pm SD values from three independent experiments. 
and D), indicating that autophagy is involved in the mechanism of the cytotoxic activity of $\mathrm{CH} 1$.

\section{DISCUSSION AND CONCLUSION}

Previous studies showed that different chalcones or their analogs exhibit a strong cytotoxic effect on the HCT-116 cells. Results of the study performed by Lima et al. indicate low $\mathrm{IC}_{50}$ values of chalcone on HCT-116 cell line after $72 \mathrm{~h}$ of treatment (24). The results of another study reported by Mohamed et al. (25) show that $\mathrm{IC}_{50}$ values of chalcones incorporated pyrazole moiety on HTC-116 cells were in the range of 3.5 to $10.4 \mu \mathrm{M}$ after $48 \mathrm{~h}$ of treatment. It should also be noted that other chalcones exhibit lower cytotoxic effect in variety tumors $(26,27)$. In our previous study (28) we have shown that one of the investigated chalcone analog, (E)-1-(4-ethoxy-3-Methoxyphenyl)-5-Methylhex-1-en-3-one showed a strong cytotoxic effect on HeLa cell line with significantly lower $\mathrm{IC}_{50}$ values compared to the values of cisplatin. Saito et al. (10) showed that two different chalcones derivate 19 and 26 had a strong antiproliferative effect on different androgen-independent prostate cancer cell lines LNCaP (DHT-), LNCaP (DHT+) and (bPC-3 and DU145) with $\mathrm{IC}_{50}$ values from 3.74$6.30 \mu \mathrm{M}$. However, evaluation of the antiproliferative effect of these chalcones on A549, MDA-MB-231, $\mathrm{MCF}-7, \mathrm{~KB}$ (originally isolated from epidermoid carcinoma of the nasopharynx) and KB-VIN (P-gp-overexpressing MDR subline of $\mathrm{KB}$ ) showed higher $\mathrm{IC}_{50}$ values (10). The study conducted by $\mathrm{Xu}$ et al. (29) showed that chalcone derivate L2H17 had growth inhibitory effect on different colon cancer cell lines (SW620, HCT-116 and CT26.WT). In another study effect of chalcone derivate, derived from combined moiety of millepachine and phenstatin was evaluated on five different human cancer cell lines A549, HeLa, HCT-116, A2780 and MGC803 (12). The results of the antiproliferative activity assay showed that investigated hybrids exhibited better antiproliferative activity compared to original compound millepachine. In our study, for the first time, we have shown that our newly synthesized vanillin based chalcone analogs exhibited a strong antitumor on effect on colorectal cancer cells. In support of this, we demonstrated that $\mathrm{CH} 1$ and $\mathrm{CH} 2$ induced apoptosis in colon cancer cells and increased cytotoxicity of the HCT116 cell line at low $\mu \mathrm{M}$ concentrations. Also, we have shown that our chalcones didn't affect the cytotoxicity of MRC-5 cells that were healthy non-cancerous control.

Referent substances, cisPt and DHZ also exhibited significant cytotoxic effect on HCT-116 cell line; with high calculated $\mathrm{IC}_{50}$ values for healthy MRC-5 cell line. Similar results regarding the cytotoxic effect of cisPt and DHZ were obtained in numeral studies. Son et al. (30) showed that $\mathrm{IC}_{50}$ values for cisplatin during $24 \mathrm{~h}$ treatment of HCT-116 cells were similar to our calculated values. In another experimental model, mouse colon-26 cell line (CT-26) showed higher sensitivity to cisplatin with lower $\mathrm{IC}_{50}$ values (31). Dehydrozingerone based cyclopropyl derivatives (21) expressed cytotoxic activity against (HeLa, LS174 and A549) cells without significant cytotoxic influence on noncancerous cell line (MRC-5).

In 2018 Nomenclature Committee on Cell Death (NCCD) has formulated recommendations for the definition of cell death morphotypes (7). For the classification of cell death type different biochemical assays and morphological characteristics of the dying cell were determined. The changes in the cell morphology including cell shrinkage, attachment loss, membrane blebbing, formation of apoptotic bodies were defined as PCD (programmed cell death), apoptosis (7). After we have determined the cytotoxic effect of chalcone analogs, next we have evaluated their effect on the morphology of HCT116 cells. Different literature sources indicated the presence of morphological changes of the cell treated with chalcone derivate or their analogs. These reported morphological changes of treated cells were common to the type I of the cell death, apoptosis. Mielcke et al. (32) investigated the effects of quinoxaline-derived chalcones on the viability of human and rat (HN30 and SCC-158) oral squamous cell carcinoma cell line (32). Their results indicated that quinoxaline-derived chalcone had a strong cytotoxic effect with morphological changes that corresponded to PCD (apoptosis). In our previous study conducted by Luković et al. (28) we have also reported changes in the morphology of HeLa cell line after chalcone analog treatment. Results of our study indicated that chalcone analogs induced both cytotoxic and morphological changes of cells which were related to apoptotic changes (28).

In order to confirm chalcone induced apoptosis, determination of biochemical characteristics along with cytotoxic effects and morphological changes of treated cells is acquired. Annexin-V staining of phosphatidylserine can be combined with a dead cell dye such as PI or 7-AAD that stains the DNA of cells with permeable membranes (33). The results of our study indicate that our investigated chalcone analogs induce apoptosis in HCT-116 treated cells. The literature data confirmed our findings. In studies performed by a) de Vasconcelos et al. (34) treatment of HT-29 cells with chalcone 
derivatives of 2-acetyl thiophene; b) treatment of HeLa cells with chalcone analog (E)-1-(4-ethoxy-3methoxyphenyl)-5- methylhex-1-en-3-one (28) c) treatment of H460 and H157 with (2'-hydroxy4',5'-dimethoxychalcone) - HDMC (35) induced apoptosis. We have also shown that apoptosis represents the main type of cell death of HCT-116 cells after treatment with our chalcone analogs. Results obtained from Annexin V-FITC/7-AAD assay showed that both $\mathrm{CH} 1$ and $\mathrm{CH} 2$ induced apoptosis with a high percentage of apoptotic and negligible percent of necrotic cells.

In order to distinguish inner from outer apoptotic pathway determination of expression levels of crucial apoptotic proteins was required. In a study performed by Zhou et al. authors reported that diverse molecular targets were crucial for chalcones varied bioactivities (36). Some chalcones displayed marked antiproliferative effects, via apoptosis and autophagy induction (32) others enhance TRAILinduced apoptosis (37) or ROS production (38) etc. Numerous chalcones derivate mentioned in the previous section induced apoptosis via inner mitochondrial pathway through overexpression of Bax protein and active caspase- $3(28,34,35)$. Our results indicated that chalcone analog treatment of HCT116 cells caused overexpression of active, mitochondrial pro-apoptotic Bax protein and active caspase-3 compared to the control cells. To prove that our chalcone analogs induced apoptosis in HCT-116 cells, we analyzed the expression level of active Bax (Fig. 6) and the activity of caspase-3 (Figs. 7 and 8). Our results have shown that both chalcones increased the presence of activated caspase-3, mainly in the nucleus of HCT-116 cells, indicating caspase-3 major role in the progression of apoptosis (39) (Fig. 7). Overexpression of Bax (Fig. 6) and active caspase-3 (Figs. 7 and 8) were detected using the flow cytometry and immunofluorescence method, respectively.

Numerous studies indicated the role of autophagy in chalcone induced cell death. Chang et al. (40) showed that chalcone flavokawain B (FKB) induced autophagic-cell death via reactive oxygen species (ROS) mediated signaling pathway in human gastric cancer cells (AGS/NCI-N87/KATOIII/TSGH9201). However, chalcones expressed different types of action. Zhao et al. (41) reported that isobavachalcone induced apoptosis and autophagyrelated cell death in H929 myeloma cells. The authors indicated that inhibition of autophagy with chloroquine enhanced cell death and increased number of Annexin V-positive cells. In order to find out the role of autophagy in apoptosis induced with our chalcone analogs, HCT-116 cells were co-treated with CQ (Fig. 9). Our results showed that both substances induced marked autophagy in HCT-116. However, inhibition of autophagy in $\mathrm{CH} 2$-treated cells didn't affect apoptosis induction, thus indicating that autophagy is not involved in the cytotoxic action of this compound. In contrast, in CH1-treated cells, co-treatment with CQ resulted in a decrease in the percentage of apoptotic cells pointing to autophagy as one of the mechanisms that contributed to the execution of cell death.

Our results indicate possible usefulness of $\mathrm{CH} 1$ and $\mathrm{CH} 2$ vanillin based chalcone analogs in antitumor therapy.

\section{Acknowledgements}

This study was financially supported by Faculty of Medical Sciences, University of Kragujevac (JP14/17), the project called 'Preklinička ispitivanja bioaktivnih supstanci (PIBAS) ', registry number 41010 and Prof. Predrag Đurdjević for technical support.

\section{Conflict of interest}

The authors declare no conflicts of interest.

\section{REFERENCES}

1. Granados-Romero J.J., Valderrama-Trevińo A.I., Contreras-Flores E.H., Barrera-Mera B., Enríquez M.H., et al.: Int. J. Res. Med. Sci. 5, 4667 (2017).

2. Siegel R., Miller K., Jemal A.: Cancer J. Clin. 65, 29 (2015).

3. Bintintan V.V.: EBioMedicine. 31, 11 (2018).

4. Boelens P.G., Velde C.J.H. Van De, Watanabe T.: HHS Public Access 1, 1 (2016).

5. Haggar F.A., Boushey R.P.: Clin. Colon Rectal Surg. 22, 191 (2009).

6. Lièvre A., Bachet J.B., Le Corre D., Boige V., Landi B., et al.: Cancer Res. 66, 3992 (2006).

7. Galluzzi L., Vitale I., Aaronson S.A., Abrams J.M., Adam D., et al.: Cell Death Differ. 25, 486 (2018).

8. Manchanayakage R.: ACS Symposium Series 1233, 111 (2016).

9. Heller L., Schwarz S., Perl V., Köwitsch A., Siewert B., Csuk R.: Euro. J. Med Chem. 101, 391 (2015).

10. Saito Y., Mizokami A., Tsurimoto H., Izumi K., Goto M., Nakagawa-Goto K.: Euro. J. Med. Chem. 157, 1143 (2018). 
11. Wu W., Liu Y., Ye H., Li Z.: Phyto. Res. 6180, 1 (2018).

12. An B., Zhang S., Yan J., Huang L., Li X.: Org. Biomol. Chem. 15, 852 (2017).

13. Dhar R., Kimseng R., Chokchaisiri R., Hiransai P., Utaipan T., et al.: Immunopharm. Immunotox. 40, 43 (2018).

14. Vijaya Bhaskar Reddy M., Hung H.Y., Kuo P.C., Huang G.J., Chan Y.Y., et al.: Bioorg. Medic. Chem. Lett. 27, 1547 (2017).

15. Niu H., Wang W., Li J., Lei Y., Zhao Y., et al.: Euro. J. Medic. Chem. 138, 212 (2017).

16. Peng S., Hou Y., Yao J., Fang J.: Food Func. 8, 997 (2017).

17. Wang L., Chen H.C., Yang X., Tao J.J., Liang G., et al.: Neur. Regen. Res. 13, 1665 (2018).

18. Muškinja J., Ratkovi Z., Rankovi B., Kosani M.: Kragujevac J. Sci. 38, 97 (2016).

19. Taguchi T., Nazneen A., Abid M.R., Razzaque M.S.: Contrib. Nephrol. 148, 107 (2005).

20. Dasari S., Tchounwou B.P.: Euro. J. Pharm. 740, 364 (2014).

21. Burmudžija A.Z., Muškinja J.M., Kosanić M.M., Ranković B.R., Novaković S.B., et al.: Chem. Biodivers. 14, e1700077 (2017).

22. Kubra I.R., Bettadaiah B.K., Murthy P.S., Rao L.J.M.: J. Food Sci. Tech. 51, 245 (2014).

23. Guda R., Korra R., Balaji S., Palabindela R., Eerla R., et al.: Bioorg. Medic. Chem. Lett. 27, 4741 (2017).

24. Lima R.S., Perez C.N., da Silva C.C., Santana M.J., Queiroz Júnior L.H.K., et al.: Arab. J. Chem. 13, 1 (2016).

25. Mohamed M.F., Mohamed M.S., Shouman S.A., Fathi M.M., Abdelhamid I.A.: Appl. Biochem. Biotechno. 168, 1153 (2012).

26. Abu N., Akhtar M.N., Yeap S.K., Lim K.L., Ho W.Y., et al.: PLoS ONE 9, 1 (2014).
27. Tang Y., Simoneau A.R., Xie J., Shahandeh B., Zi X.: Cancer Prev. Res. 1, 439 (2008).

28. Luković J., Mitrović M., Zelen I., Čanović P., Zarić M., Nikolić I.: Serb. J. Exp. Clin. Res. 0, 1 (2018).

29. Xu S., Chen M., Chen W., Hui J., Ji J., et al.: BMC Cancer 15, 870 (2015).

30. Son D.J., Hong J.E., Ban J.O., Park J.H., Lee H.L., et al.: Biomed. Res. Int. 2015, 1 (2015).

31. Chen H.M., Lai Z.Q., Liao H.J., Xie J.H., Xian Y.F., et al.: Int. J. Mol. Med. 41, 1447 (2018).

32. Mielcke T.R., Muradás T.C., Filippi-Chiela E.C., Amaral M.E.A., Kist L.W., et al.: Sci. Rep. 7, 15850 (2017).

33. Telford W.G.: Methods Mol. Biol. 1678, 167 (2018).

34. de Vasconcelos A., Campos V.F., Nedel F., Seixas F.K., Dellagostin O.A., et al.: Cell Biochem. Funct. 31, 289 (2013).

35. Yang L., Su L., Cao C., Xu L., Zhong D., et al.: IUBMB Life 65, 533 (2013).

36. Zhou B., Xing C.: Med. Chem. (Los Angeles) 5, 388 (2015).

37. Szliszka E., Jaworska D., Kłósek M., Czuba Z.P., Król W.: Int. J. Mol. Sci. 13, 15343 (2012).

38. Stang C.R.T., Adams B.R., Faler A.D., Schuler B.R., Eichel A.M., et al.: FASEB J. 31, 670.10 (2012).

39. Kamada S., Kikkawa U., Tsujimoto Y., Hunter T.: J. Biol. Chem. 280, 857 (2005).

40. Chang C.T., Hseu Y.C., Thiyagarajan V., Lin K.Y., Way T.D., et al.: Arch. Toxicol. 91, 3341 (2017).

41. Zhao S., Ma C.M., Liu C.X., Wei W., Sun Y., et al.: Int. J. Mol. Med. 30, 939 (2012).

(C) 2020 by Polish Pharmaceutical Society. This is an open access article under the CC BY NC license (c) (i) (8) (http://creativecommons.org/licenses/BY/4.0/). 